\title{
Remote microscopy diagnostics for pre-clearance export of apricots grown in Central Otago
}

\author{
B. Attfield ${ }^{1}$ and D. Anderson ${ }^{2}$ \\ ${ }^{1}$ Plant \& Food Research, Clyde, Central Otago, New Zealand \\ ${ }^{2}$ Plant Health E Environment Laboratory, Ministry for Primary Industries, Christchurch, New Zealand \\ Corresponding author: bernie.attfield@plantandfood.co.nz
}

Central Otago growers wishing to export apricots to Australia are required to have fruit graded, packed and inspected by a registered packhouse as part of the Offshore Pre-Clearance Inspection Programme. As part of this programme, an Australian government inspector is brought to Central Otago by the industry for approximately 6 weeks to carry out fruit inspections in the packhouse, specifically targeting insect interceptions. Any insects found in the 600 fruit sampled from each lot inspected (0.5-30 pallets) are brought to Plant \& Food Research, Clyde, where a technician prepares the specimen for remote microscopy diagnostics (RMD). RMD enables same-day insect identification by experts from the Plant Health and Environment Laboratory, Ministry for Primary Industries, Christchurch. A camera mounted on a compound or stereo microscope relays images in real time via the internet, enabling the specimen to be manipulated by the technician in Clyde for identification by qualified staff in Christchurch. Previously, insect identification took approximately 3 days, as specimens were sent by courier from Central Otago to a certified laboratory in Auckland. RMD real time saving equates to less fruit spoilage and less disruption to transport systems awaiting shipments to be cleared.

\section{Survival and reproduction of Liberibacter-infected tomato potato psyllid reared under cold environmental conditions}

\author{
W.R.M. Sandanayaka, V.A. Davis and G.P. Walker \\ Plant E Food Research, Private Bag 92-169, Auckland 1142, New Zealand \\ Corresponding author: manoharie.sandanayaka@plantandfood.co.nz
}

The tomato potato psyllid (TPP, Bactericera cockerelli) survives on volunteer potatoes growing in frost-free areas in winter in the Auckland region and therefore could transmit Candidatus Liberibacter solanacearum (Lso) to commercial crops. The survival and oviposition of laboratory-reared Lsoinfected TPP were tested under four selected environmental conditions: $12: 12 \mathrm{~h}$ light:dark at $10^{\circ} \mathrm{C}$; 13:11 h light:dark at $12^{\circ} \mathrm{C} ; 14: 10 \mathrm{~h}$ light:dark at $14^{\circ} \mathrm{C}$; and $15: 9 \mathrm{~h}$ light:dark at $16^{\circ} \mathrm{C}$, on excised leaves from volunteer potatoes (grown in the field during winter) and tomato (grown in the glasshouse). One hundred pairs of adult TPP (10 pairs/leaf) were tested on either potato or tomato in each environmental condition for 7 days. Survival of females on potato or tomato was not significantly different between treatments. Significantly more males survived on both potato and tomato at $10^{\circ} \mathrm{C}$ than at $14^{\circ} \mathrm{C}$ or $16^{\circ} \mathrm{C}$. The number of eggs deposited on both plant species increased with increasing temperature and photoperiod but remained unhatched in all tested temperatures. Results revealed that Lso-infected TPP could feed (as indicated by excretory droplets), oviposit and survive on volunteer potatoes in Auckland winter-like conditions and potentially transmit Lso to crops grown in these cooler months. 